\title{
Sudanese traditional stains for staining some biological samples
}

\author{
Hiba Siddig Ibrahim $^{1^{*}}$ and Shamsoun Khamis Kafi ${ }^{1}$
}

Ibrahim HS and Kafi SK. Sudanese traditional stains for staining some biological samples. Curr Res Integr Med 2017;2(1):10-12.

Taifta, cloth dye and paints were considered as one of the Sudanese colours that was extracted from Sudanese rocks; it used to colour traditional handworks such as Palm Sunday (local name; saaf), prayers carpets while the second dye used to stain clothes in addition to the third one ElMohandis paints (water base painting) that used for synthetic enamel and emulsion paints. All those dyes were used in this study to stain some bacteriological smears in addition to blood films to study the possibility of using these stains in the future to stain some medical samples in case of safe stain, ruler areas to avoid travels cost, good staining, availability of stain, and low cost too.

In this study, we have used different staining colours with the different procedures to study the possibility of staining of some biological samples with those traditional Sudanese dyes; beside ability to uses those stains in the future to stain other kind of biological samples such as histopathological samples, in cosmetics, medical tabs and also to colour food.

Key Words: Taifta, S. pyogens, K. pneumoniae, Coomassie blue.
Staining is an old procedure that humans used from the beginning of life Suntil now by different techniques for different uses, but in this study is concerned about medical stains especially local traditional stains such as taifta, paints and fabric paints to stain some biological samples such as bacterial smears and human blood films as a way to use these traditional stains in the faraway laboratories in rural areas.

The importance of staining technique in the medical fields

Staining is an auxiliary technique used in microscopy to enhance contrast in the microscopic image, stains they were frequently used in biology and medicine to highlight structures in biological tissues for viewing muscle fibers or connective tissue, cell populations such as different blood cells, organelles within individual cells, DNA, proteins, lipids, carbohydrates compound, to mark cells in flow cytometry, and to flag proteins or nucleic acids in gel electrophoresis, lamellar structures of semi-crystalline polymers or the domain structures of block copolymers $(1,2)$.

Staining can be simple that's contains only one stain/dye, or complicated that contains more the one dye or stains, such as; counterstaining or negative staining, differential staining, or both. Also, staining can be used in vivo; which is the process of dyeing living tissues (vital stain) or in vitro staining that used to colour cells or structures that have been removed from their biological context $(1,2)$.

\section{Most common used laboratory stains}

1) Romanowsky stain that's named after the Russian physician Dmitri Leonidovich Romanowsky (1861-1921), who invented it, in 1891. It based on a combination of eosinate (chemically reduced eosin) and methylene blue (sometimes with its oxidation products azure A and azure $\mathrm{B}$ for staining and examination of blood or bone marrow films $(1,3,4)$.

2) Gram stains named after the Danish bacteriologist who originally devised it in 1882 (published in 1884), Hans Christian Gram, it is one of the most important staining techniques in microbiology. It is almost; always the first test that performed for the identification of bacteria because it separates almost all bacteria into two large groups: Gram-positive bacteria that stain blue and the Gramnegative bacteria that stain pink (2,5-9).

3) Others laboratory staining are: Endospore staining, Ziehl-Neelsen stain, Haematoxylin and eosin (H\&E) staining, Papanicolaou staining or pap stain, PAS (Periodic acid-Schiff) staining, Masson's trichrome, Silver staining, Sudan staining, Conklin's staining, Acridine orange $(\mathrm{AO})$, Bismarck brown or Manchester brown, Carmine, Coomassie blue etc. (1).

\section{METHODS}

Preparation of bacteriological smear

Two chocolate agars plates that contained either S. pyogens or K. pneumoniae were brought out of the incubator for madding two different kinds of smears from both organisms. Dust free slide were brought and passed three times under the benzene burner for sterilization, waiting to cool, a colony from zig zag area was taken by loop then added to slides that contains a drop of normal saline, mix, waiting to dry and fixed by passing through the flame three times for fixations.

\section{Preparation of blood film}

Venous blood from cubical vein was collected in EDTA tube after sterilizing the collection area with $70 \%$ alcohol; a blood drop was added in dust clean free slide, spreading by spreader at 45 angels, drying and fixation with absolute alcohol for few seconds or until alcohol evaporation.

\section{Preparation of taifta}

Two gram from taifta were measured by sensitive balance in clean sterilized containers followed by adding $100 \mathrm{ml}$ of tape water, mix until all stains powered dissolved, now the stain was ready to use.

\section{Preparation of paints}

A little amount from paints paste $(2 \mathrm{~g})$ were added to clean sterile containers followed by adding $50 \mathrm{ml}$ of tape water, mix then the stain was ready to be used.

\section{Preparation of fabrics colour}

A little amount from fabrics colour paste $(2 \mathrm{~g})$ were added to clean sterile containers followed by addition of water to complete the volume to $40 \mathrm{ml}$ and mix, the stain was ready to use.

\section{Tafita staining procedure}

Eight slides were brought into the staining rack, $2 \mathrm{ml}$ from each Tafita were added to each slides, waiting 3 minutes, after that washed the slides with tape water and leave them to dried by air; the same procedure was applied with tafita mix after mixing equal volume from tafita staining solutions or tafita red was added first to slides, waiting 3 minutes for staining, after that washed the slide with tape water, then tafita blue was added for 2 minutes, washed by tape water and drying by air; while for Tafita-zn, tafita red was added to the slides first followed by heating until presence of steam, waiting for 3 minutes, washed with tape water, tafita blue were added for 2 minutes, washed by tape water and drying by air.

${ }^{1}$ Department of Microbiology and Parasitology, National Ribat University, Khartoum, Sudan, ${ }^{2}$ Department of Microbiology-Virology, National Ribat University, Khartoum, Sudan

Correspondence: Hiba Siddig Ibrahim Mustafa, National Ribat University, Nile Street Burri, Khartoum, Sudan-11111, Telephone: 249909503862, E-mail: hibasiddig55@ gmail.com.

Received: January 02, 2017, Accepted: March 27, 2017, Published: April 02, 2017 


\section{Paints staining procedure}

Three Slides were brought to the staining racks, $3 \mathrm{ml}$ from Paints colour were added to each slides, waiting for 10 minutes, washed the film with tape water and drying by air.

For mixed paints coloured, the same procedure as above were applied after mixing equal amount from both red and green paints solutions.

Fabric colour staining procedure

Two slides were brought to the staining racks, $3 \mathrm{ml}$ from Fabric colour were added to each slide and waiting for 10 minutes then washed the films with tape water, drying by air.

\section{RESULTS}

Traditional local Sudanese stains showed a good staining results within a different kind of biological samples and organisms, please review the Tables 1 and 2 for more details.

TABLE 1

Illustrate smears and blood films results with traditional stains

\begin{tabular}{|c|c|c|c|c|c|c|c|}
\hline $\begin{array}{c}\text { Types } \\
\text { of stain }\end{array}$ & $\begin{array}{c}\text { Total } \\
\text { number } \\
\text { of cocci } \\
\text { smear }\end{array}$ & $\begin{array}{c}\text { Total } \\
\text { Number } \\
\text { of bacilli } \\
\text { smear }\end{array}$ & $\begin{array}{c}\text { Total } \\
\text { number } \\
\text { of blood } \\
\text { smear }\end{array}$ & $\begin{array}{l}\text { Stain } \\
\text { results } \\
\text { for } \\
\text { cocci }\end{array}$ & $\begin{array}{l}\text { Stain } \\
\text { results for } \\
\text { bacilli }\end{array}$ & $\begin{array}{c}\text { Stain } \\
\text { results } \\
\text { for blood } \\
\text { film }\end{array}$ & $\begin{array}{c}\text { Total } \\
\text { number } \\
\text { of } \\
\text { slides }\end{array}$ \\
\hline $\begin{array}{l}\text { Taifta } \\
\text { red }\end{array}$ & 5 & 5 & 5 & $\begin{array}{l}\text { Positive } \\
\text { red } \\
\text { colour } \\
\text { cocci }\end{array}$ & $\begin{array}{l}\text { Positive } \\
\text { red colour } \\
\text { bacilli }\end{array}$ & $\begin{array}{l}\text { Positive } \\
\text { with } \\
\text { different } \\
\text { degree } \\
\text { red } \\
\text { colour } \\
\text { for both } \\
\text { RBCs } \\
\text { and } \\
\text { WBCs }\end{array}$ & 15 \\
\hline $\begin{array}{l}\text { Taifta } \\
\text { blue }\end{array}$ & 5 & 5 & 5 & $\begin{array}{l}\text { Positive } \\
\text { blue } \\
\text { colour } \\
\text { cocci } \\
\text { with little } \\
\text { deposit }\end{array}$ & $\begin{array}{c}\text { +ve faint } \\
\text { blue } \\
\text { colour } \\
\text { bacilli }\end{array}$ & $\begin{array}{l}\text { Positive } \\
\text { with } \\
\text { different } \\
\text { degree } \\
\text { blue/ } \\
\text { green } \\
\text { RBCs } \\
\text { and } \\
\text { WBCs } \\
\text { colour }\end{array}$ & 15 \\
\hline $\begin{array}{l}\text { Taifta } \\
\text { brown }\end{array}$ & 5 & 5 & 5 & $\begin{array}{c}\text { Positive } \\
\text { brown } \\
\text { colour } \\
\text { cocci }\end{array}$ & $\begin{array}{c}\text { Positive } \\
\text { brown } \\
\text { colour } \\
\text { bacilli } \\
\text { (less in } \\
\text { number } \\
\text { and mix } \\
\text { with cocci }\end{array}$ & $\begin{array}{l}\text { Positive } \\
\text { brown or } \\
\text { yellow } \\
\text { RBCs } \\
\text { colour } \\
\text { + red } \\
\text { WBCs } \\
\text { colour }\end{array}$ & 15 \\
\hline $\begin{array}{l}\text { Taifta } \\
\text { mix } 1\end{array}$ & 5 & 5 & 5 & $\begin{array}{l}\text { Positive } \\
\text { red } \\
\text { colour } \\
\text { cocci }\end{array}$ & $\begin{array}{l}\text { Unclear/ } \\
\text { faint film }\end{array}$ & $\begin{array}{c}\text { Positive } \\
\text { red/ } \\
\text { violet } \\
\text { WBCs } \\
\text { colour } \\
\text { with blue } \\
\text { back }\end{array}$ & 15 \\
\hline $\begin{array}{c}\text { Taifta- } \\
\text { zn }_{2}\end{array}$ & 5 & 5 & - & $\begin{array}{l}\text { Positive } \\
\text { red } \\
\text { colour } \\
\text { cocci } \\
\text { with blue } \\
\text { back } \\
\text { ground }\end{array}$ & $\begin{array}{c}\text { Unclear } \\
\text { film/ faint } \\
\text { blue bacilli }\end{array}$ & - & 10 \\
\hline $\begin{array}{l}\text { Black } \\
\text { dye }\end{array}$ & 5 & 5 & - & $\begin{array}{l}\text { Positive } \\
\text { black } \\
\text { colour } \\
\text { cocci }\end{array}$ & $\begin{array}{c}\text { Positive } \\
\text { black } \\
\text { colour } \\
\text { bacilli }\end{array}$ & - & 10 \\
\hline $\begin{array}{l}\text { Red } \\
\text { paints }\end{array}$ & - & 5 & 5 & - & $\begin{array}{l}\text { Positive } \\
\text { red colour }\end{array}$ & $\begin{array}{l}\text { Positive } \\
\text { pale } \\
\text { red or } \\
\text { yellowish } \\
\text { RBCS } \\
\text { Positive } \\
\text { to violet } \\
\text { WBCS } \\
\text { colour }\end{array}$ & 10 \\
\hline
\end{tabular}

\begin{tabular}{|c|c|c|c|c|c|c|c|}
\hline $\begin{array}{l}\text { Green } \\
\text { paints }\end{array}$ & - & 5 & 5 & - & $\begin{array}{c}\text { Positive } \\
\text { green } \\
\text { colour } \\
\text { bacilli }\end{array}$ & $\begin{array}{l}\text { Positive } \\
\text { pale } \\
\text { red or } \\
\text { yellowish } \\
\text { RBCs } \\
+ \text { green } \\
\text { WBCs } \\
\text { colour }\end{array}$ & 10 \\
\hline $\begin{array}{c}\text { Mix } \\
\text { paints-3 }\end{array}$ & - & - & 5 & - & - & $\begin{array}{l}\text { Positive } \\
\text { yellowish } \\
\text { or pale } \\
\text { red } \\
\text { RBCS } \\
\text { + red to } \\
\text { violet } \\
\text { WBCS } \\
\text { colour }\end{array}$ & 5 \\
\hline $\begin{array}{c}\text { Red } \\
\text { fabric } \\
\text { colour }\end{array}$ & - & - & 5 & - & -- & $\begin{array}{c}\text { Positive } \\
\text { red } \\
\text { RBCs }\end{array}$ & 5 \\
\hline $\begin{array}{l}\text { Blue } \\
\text { fabric } \\
\text { colour }\end{array}$ & - & - & 5 & - & - & $\begin{array}{l}\text { Positive } \\
\text { Blue } \\
\text { RBCs } \\
\text { Positive } \\
\text { violet } \\
\text { WBCs }\end{array}$ & 5 \\
\hline Total & 30 & 40 & 45 & & & & 115 \\
\hline
\end{tabular}

TABLE 2

Illustrate traditional stains quality

\begin{tabular}{|c|c|c|c|}
\hline Types of stain & $\begin{array}{c}\text { Quality of } \\
\text { stain for cocci }\end{array}$ & $\begin{array}{c}\text { Quality of } \\
\text { stain for bacilli }\end{array}$ & Quality of stain blood film \\
\hline Taifta red & Good & Good & Good \\
\hline Taifta blue & $\begin{array}{l}\text { Good + little } \\
\text { amount of } \\
\text { deposit }\end{array}$ & Faint & $\begin{array}{l}\text { Neither good nor bad }+ \text { blue } \\
\text { or green background make it } \\
\text { the film difficult to interrupt }\end{array}$ \\
\hline Taifta brown & Good & Good & Good \\
\hline Taifta mix & Good & Faint & Good + blue background \\
\hline Taifta-zn & Good & Faint & - \\
\hline Black dye & $\begin{array}{l}\text { Good }+ \\
\text { moderate } \\
\text { amount of } \\
\text { deposit }\end{array}$ & Good & - \\
\hline Red paints & & & Good \\
\hline Green paints & & - & Good \\
\hline Mix paints & - & - & Good \\
\hline $\begin{array}{l}\text { Red fabrics } \\
\text { colour }\end{array}$ & - & - & Neither good nor bad \\
\hline $\begin{array}{l}\text { Blue fabrics } \\
\text { colour }\end{array}$ & - & - & Neither good nor bad \\
\hline
\end{tabular}

\section{DISCUSSION AND CONCLUSION}

Dying and staining procedure were considered the most important techniques in medical filed, industries, foods, decoration, cosmetics and artist, here I was concerned for the first one; the medical filed specially laboratories due to ability of dye for staining different kinds of cells, tissues and organisms; as I mentioned before the main aim of this study is to study the possibility of staining some biological samples by using traditional Sudanese dye/stains; according to these, I found that, traditional Sudanese dye can be used to stain some biological samples with a good results except in some cases with gram negative bacteria it can gives a good stain or faint coloured sometimes; according culture old, ability of bacteria to change the $\mathrm{PH}$ in the medium, or may be due to absence of buffer that can fix the $\mathrm{PH}$ of staining solution nor the staining times was too short and needs to be prolonged with gram-negative bacilli another things are that; absence of substances that can enhance taken up of stain by organism or may be due to bacteria itself, but those things nearly were not happens with a blood films instead of presence of different kinds of blood cells with a different charges inside the cells; further more blue tafita was made a very strong background colour that makes differential blood films very hard to distinguish between different kinds of blood cells, fabrics coloured when compare with tafita and paints showed neither good nor bad blood film staining technique that is 
may be due to thickness of blood films or its unsuitable to staining biological samples, now I tried to use tafita with malaria parasite but it needs more times to cover all malaria parasite stages.

\section{ACKNOWLEDGEMENT}

The author would like to thank Allah, her family for always supporting her, especially her father and also The National Ribat University; microbiology department members.

\section{STATEMENT OF COMPETING INTERESTS}

The authors declare that they have no competing interests.

\section{REFERENCES}

1. Staining, 2016. https://en.wikipedia.org/wiki/Staining.

2. Bacterial smears and simple stain http://www2.highlands.edu/academics/ divisions/scipe/biology/labs/rome/bacterial_smears_and_stains.htm
3. Horobin RW. How Romanowsky stains work and why they remain valuable -including a proposed universal Romanowsky staining mechanism and a rational troubleshooting scheme. Biotech Histochem. 2011;86(1):36-51.

4. Romanowsky stain, 2016. https://en.wikipedia.org/wiki/Romanowsky_ stain.

5. Gram Stain Technique.vlab.amrita.edu. 2011. Gram Stain Technique. Retrieved 22 December 2016, from vlab.amrita.edu/?sub=3\&brch=73\& sim $=208 \& \mathrm{cnt}=2$

6. History of the gram stain and how it works. http://www.uphs.upenn.edu/ bugdrug/antibiotic_manual/gram $1 . h t m$.

7. Jay Hardy Gram's Serendipitous Stain. 2016. http://hardydiagnostics.com/ wpcontent/uploads/2016/05/Hans-Christian-Gram.pdf

8. Microbiology staining techniques. Waksman Foundation for Microbiology: Information Resources.

9. http://www.waksmanfoundation.org/labs/rochester/grmstain.htm 